\title{
FIRST RECORD OF EVOXYMETOPON TAENIATUS (ACTINOPTERYGII: PERCIFORMES: TRICHIURIDAE) FROM THE PHILIPPINES
}

\author{
Donna M. GUARTE* and Wilfredo L. CAMPOS \\ OceanBio Laboratory, College of Arts and Sciences, University of the Philippines Visayas, Miagao, Iloilo, 5023 \\ Philippines
}

Guarte D.M., Campos W.L. 2016. First record of Evoxymetopon taeniatus (Actinopterygii: Perciformes: Trichiuridae) from the Philippines. Acta Ichthyol. Piscat. 46 (4): 361-366.

\begin{abstract}
The channel scabbardfish, Evoxymetopon taeniatus Gill, 1863 has not been known from the Philippine waters. Our presently reported finding of two specimens (114.5 and $133.1 \mathrm{~cm} \mathrm{SL})$ of this species from the Philippines extends the range of this species to the central Indo-Pacific. The specimens captured were both male, one with developing gonads, and the other one - mature. We examined and described the fish found, providing morphometric and meristic analyses. The species can be distinguished from its congeners by having a convex upper head profile, steep sagittal crest slope, 82 dorsal fin rays with a defined notched at the tenth ray, a black dorsal fin membrane before the notch, and 15 externally visible anal fin rays that are bound with a membrane. The analyses included also relations with size of the four known Evoxymetopon species. Only one significant relation was revealed by the regression analyses- between SL and \% pre-anal length. We provided also an updated identification key for the genus.
\end{abstract}

Keywords: new record, range extension, morphological description, morphometric trends, scabbardfish

The trichiurids, commonly known as cutlassfishes, hairtails, or scabbardfishes, are widely distributed in tropical to warm temperate waters. They typically live close to the bottom on the continental shelf and the upper slope, reaching the depths of 50-1500 m (rarely $2000 \mathrm{~m}$ ), with many species exhibiting diel vertical migrations (Nakamura and Parin 1993). At present, there are 47 valid species of trichiurids (Eschmeyer and Fong 2016), belonging to 11 genera (Eschmeyer et al. 2016). Of these, 9 species have been reported from the Philippine waters. "Trichiurus japonicus Temminck et Schlegel, 1844" was not among them. While the latter was earlier reported by Herre (1953) as a separate species, it is now considered a junior synonym of the wide-spread species Trichiurus lepturus Linnaeus, 1758 (Carpenter and Niem 2001, Froese and Pauly 2016). Chakraborty et al. (2006), however, believe that $T$. japonicus is a valid species, as inferred from its DNA analysis.

Trichiurids make up a large fishery worldwide, with total landings amounting to 1.26 million $\mathrm{t}$ in 2014 (Anonymous 2016c), most of which were caught in the north-west Pacific. In the Philippines, annual hairtail landings from 2002-2014 approximated $15000 \mathrm{t}$ per year (Anonymous 2016a) which is only $0.7 \%$ of the total marine-fisheries landings in the country.
This paper reports the first records of the channel scabbardfish, Evoxymetopon taeniatus Gill, 1863, in the Philippine waters. Two specimens of E. taeniatus were recorded from catches of modified hook and line fishing on two different occasions off the coast of Naba, Culasi in Antique, in western Panay Island central Philippines (Fig. 1) from 20 April to 10 May 2016. There are to date 53 recorded occurrences of this species worldwide (Anonymous 2016b), but only a few references on their biology are available. The species is reportedly more widespread in the west Atlantic (Froese and Pauly 2016). In the west Pacific, reports on its occurrence are limited to Japan, Taiwan, and Korea.

Two specimens of Evoxymetopon taeniatus were identified in this study. The first specimen measured $114.5 \mathrm{~cm} \mathrm{SL}$, while the second one- $133.1 \mathrm{~cm} \mathrm{SL}$. Both specimens were caught using handlines modified to catch trichiurids (by means of baited hooks tied to and suspended from the ends of a $1.2 \mathrm{~m}$ iron rod attached in the middle to a cylindrical lead weight at the end of the main fishing line). Identification of the species followed Gill (1863), Nakamura and Parin (1993), Sakiyama et al. (2011), Fricke et al. (2014), and Hata et al. (2015).

Standard morphometric measurements were taken following Hata et al. (2015), whereby length measurements are expressed as percentages $(\%)$ of the specimen's standard 


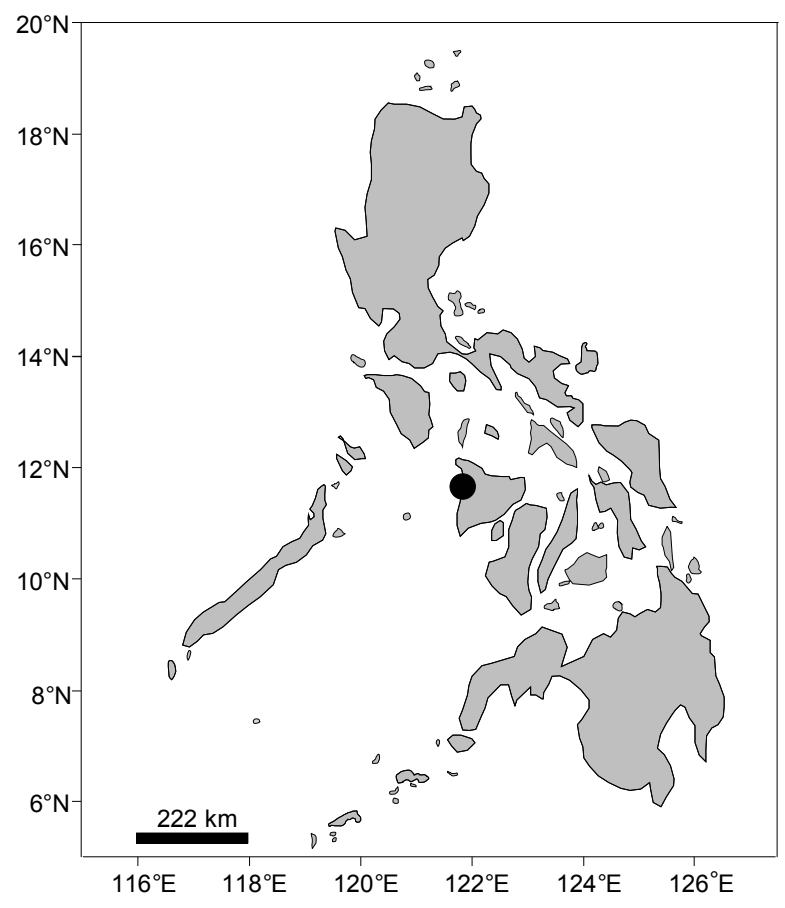

Fig. 1. Map of the Philippines showing the location of the sampling site, Culasi, Antique in Panay Island (black circle)

length (SL). Some modifications in fin counts were made, such as instead of listing down the number of total external fin rays (spinescent + external easily distinguishable rays), the count includes only the visible and distinguishable external fin rays (Fricke et al. 2014). Hence, external anal fin ray counts are presented as $x+15$, where $x$ is the number of spinescent anal rays. This modification was done because precise counting of the spinescent rays is difficult due to their very minute size, and are thus prone to miscounting. Another modification was the addition of the number of notched dorsal fin elements and the number of dorsal fin elements with a blackish membrane. These characteristics were added to help in distinguishing this species from other closely-related species in the family, where references are relatively scarce. Aside from the above, sex and maturation stages of the specimens were also noted.

Measurements and counts of Evoxymetopon taeniatus and of other Evoxymetopon species from different authors (Gill 1863, Nakamura and Parin 1993, Fricke et al. 2014, Hata et al. 2015, Sakiyama et al. 2011) were compiled and used in this study to examine relations with size and to update the identification key of the genus. For Sakiyama et al. (2011), length measurements were converted to \%SL to standardize the format and for easier comparison. Simple linear regression was employed to quantify the relations.

Family Trichiuridae Rafinesque, 1810

Genus Evoxymetopon Gill, 1863

Evoxymetopon taeniatus Gill, 1863

The specimens in this study were both males, with the smaller specimen (114.5 $\mathrm{cm} \mathrm{SL}$ ) representing the gonad developing stage, while the larger one $(133.1 \mathrm{~cm} \mathrm{SL})$ - in mature stage. Detailed descriptions of the specimens are presented below.

Short description of the Philippine specimens. Meristics and morphometrics are given in Table 1. Body elongate, slender, deep and highly compressed with triangular pectoral fin, reduced scale-like pelvic fin (Fig. 2D), and small forked caudal fin (Fig. 2E). Body silvery white, with slight reddish brown cast dorsally and several longitudinal yellow stripes on body. Head oblong with steep sagittal crest (Fig. 2C). Dorsal fin elements of sub-equal length: 82, with defined notch at 10th element (Fig. 2A-C). Colour of dorsal fin membrane before notch black and transparent thereafter (Fig. 2A-C). Externally visible anal fin rays: 15 .

Comparison with other species. The channel scabbardfish, Evoxymetopon taeniatus, is externally similar to Evoxymetopon moricheni Fricke, Golani et AppelbaumGolani, 2014, which also has a steep slope in the anterior part of the head, a crescent-shaped nostril, and no filament on the first dorsal fin spine. They however differ in the following features: E. taeniatus has 15 externally visible anal fin soft rays, versus 17 in E. moricheni; 19 lower gill rakers (vs. 13 in E. moricheni); silvery white body with longitudinal stripes (vs. plain silvery body without stripes); anterior head portion without blackish margin (vs. blackish margin on head continuing along the anterior half of the dorsal fin base); 1st to 9th dorsal fin elements with blackish membrane (vs. 1st to 5th elements only); and dorsal fin notched at the 10th element (vs. 8th through 9th element notch) (Fricke et al. 2014). Evoxymetopon taeniatus is further distinguished from the other species of the genus by its lack of a filament in the 1st dorsal fin spine. The filament is sword-like in Evoxymetopon macrophthalmus Chakraborty, Yoshino et Iwatsuki, 2006 and elongate in Evoxymetopon poeyi Günther, 1887. It has crescent-shaped nostrils (Nakamura and Parin 1993), although the shape is not clear in our specimens, and 82 (range 81-82) dorsal fin elements, while E. macrophthalmus and E. poeyi have slit-like nostrils and 90 and 91-93 dorsal fin elements, respectively. Evoxymetopon taeniatus further differs from E. macrophthalmus by not having a blackish margin on the head, and from E. poeyi by having 15 externally visible anal fin rays (vs. 20) (Fricke et al. 2014).

Morphometric trends. Fin counts and \%SL measurements of Evoxymetopon from Sakiyama et al. (2011) and Hata et al. (2015) were included in the analysis for morphometric trends (Table 1). Thus, 6 specimens were analysed for possible relations between SL and the other morphometric measurements. The regression analyses showed only one significant relation (Fig. 3), between SL and \% pre-anal length $\left(r^{2}=0.909, P=0.003\right)$. The number of dorsal fin elements, as well as lower gill raker counts also tend to increase with size, but these covered very narrow ranges (Table 1) and were not significant.

Identification key for Evoxymetopon species. Based on information reported in the literature and on the data recorded in the presently reported study, an updated identification key for the four known species 
Table 1

Counts and measurements of the two Evoxymetopon taeniatus specimens from Culasi, Antique in Panay Island, Philippines, compared with the relevant published data from Japan

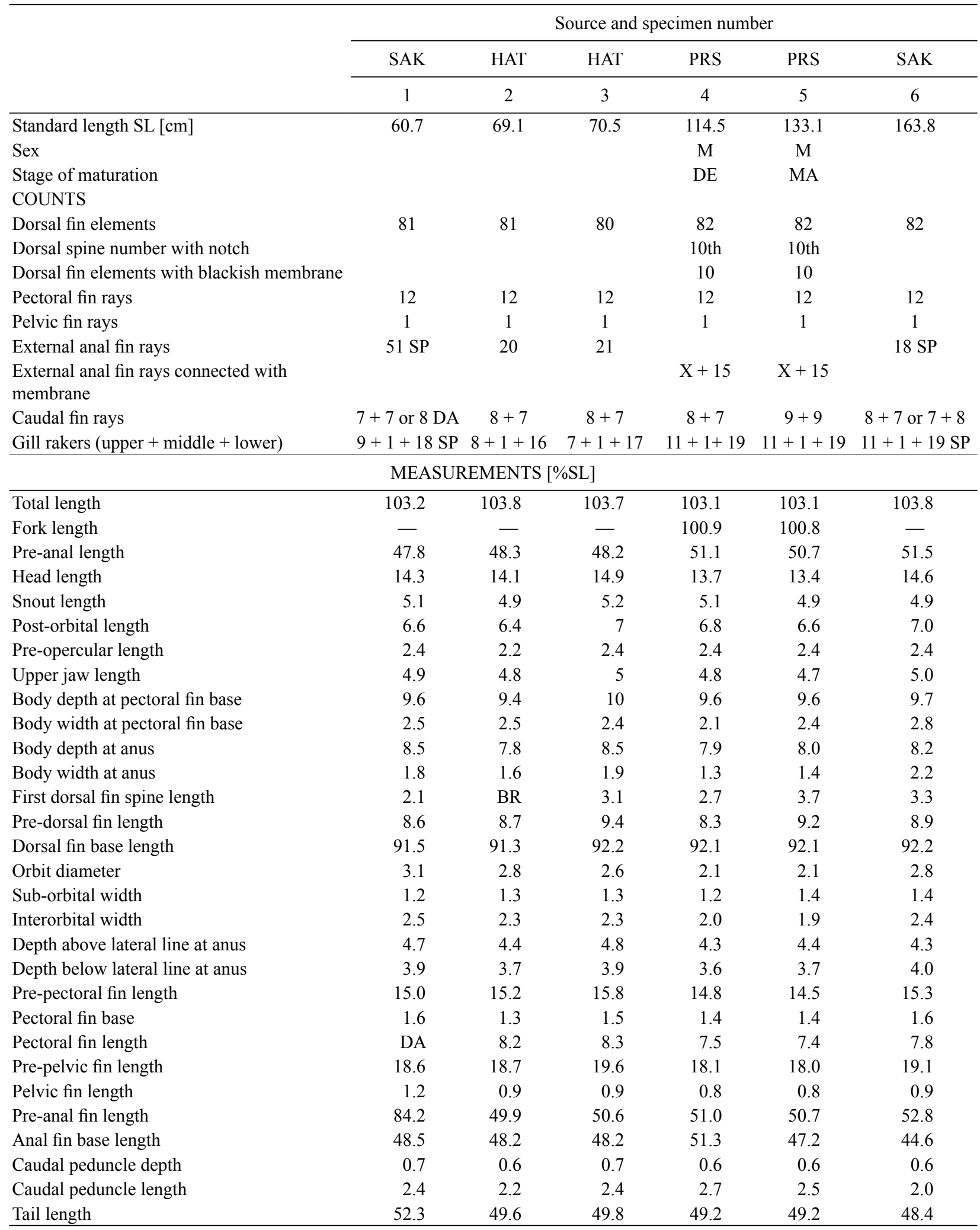

Specimens studied to date are arranged and numbered in ascending order (in respect to their standard length); SAK = Sakiyama et al. (2011) with measurements converted to $\% \mathrm{SL}, \mathrm{HAT}=$ Hata et al. (2015), $\mathrm{PRS}=$ presently reported study; $\mathrm{M}=$ male, $\mathrm{DE}=$ developing, $\mathrm{MA}=$ mature, $\mathrm{SP}=$ spinescent, $\mathrm{DA}=$ damaged, $\mathrm{BR}=$ broken . 


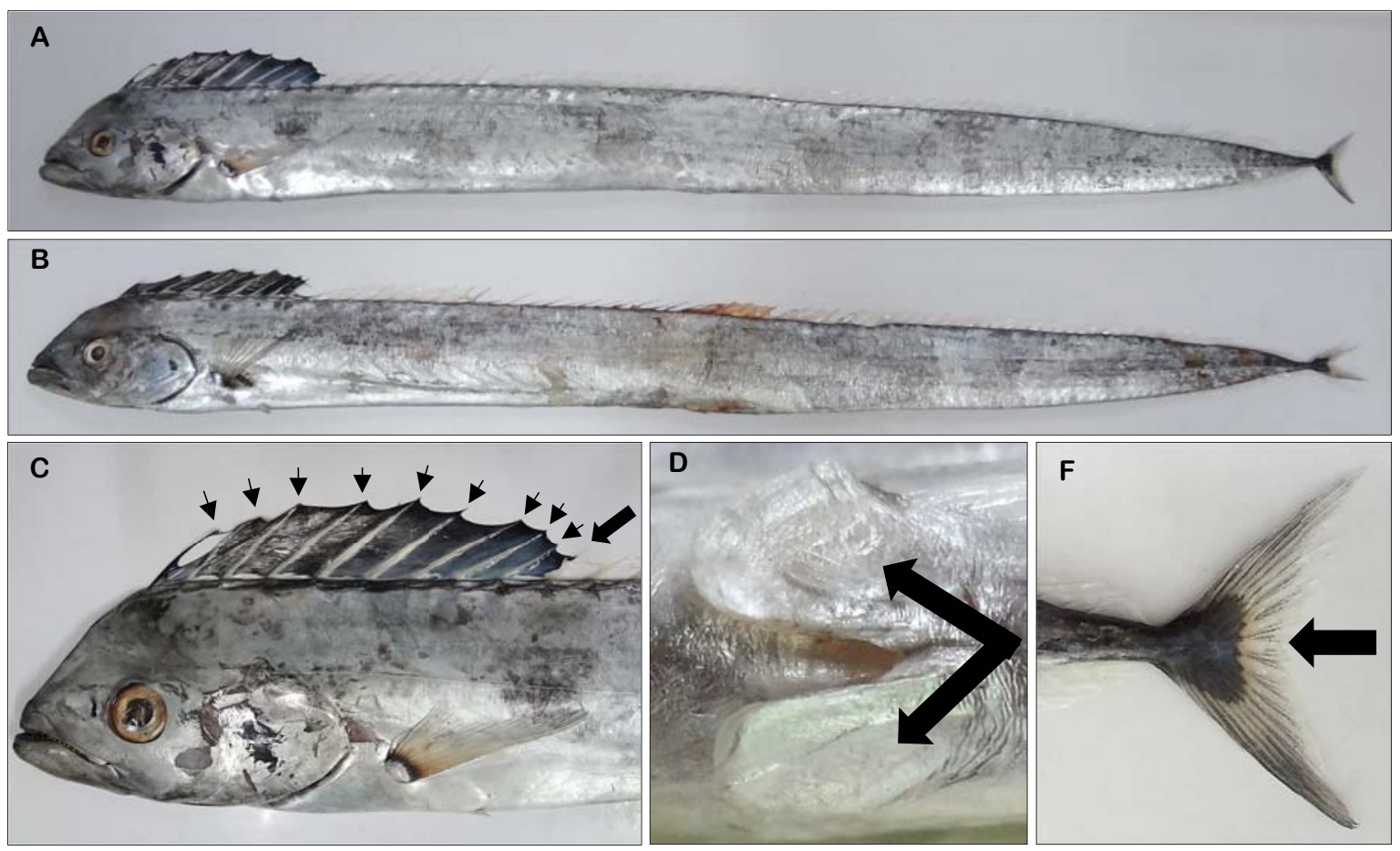

Fig. 2. Whole specimens of Evoxymetopon taeniatus from Culasi, Antique, SL $=133.1 \mathrm{~cm}$ SL (A) and SL $=114.5 \mathrm{~cm}$ SL (B); Head profile showing the sagittal crest, notched dorsal fin, and number of dorsal fin elements with blackish membrane (C); Reduced scale-like pelvic fins (D); Small forked caudal fin (E)

of Evoxymetopon (Family Trichiuridae) is presented below. All species have continuous single dorsal fin, small forked caudal fin, and reduced (scale-like) pelvic fins (Fig. 2). Although, the shape of the nostril (slitlike vs. crescent-shaped) is one of the distinguishing characteristics of the four species, this character is not included in the identification guide because the nostril

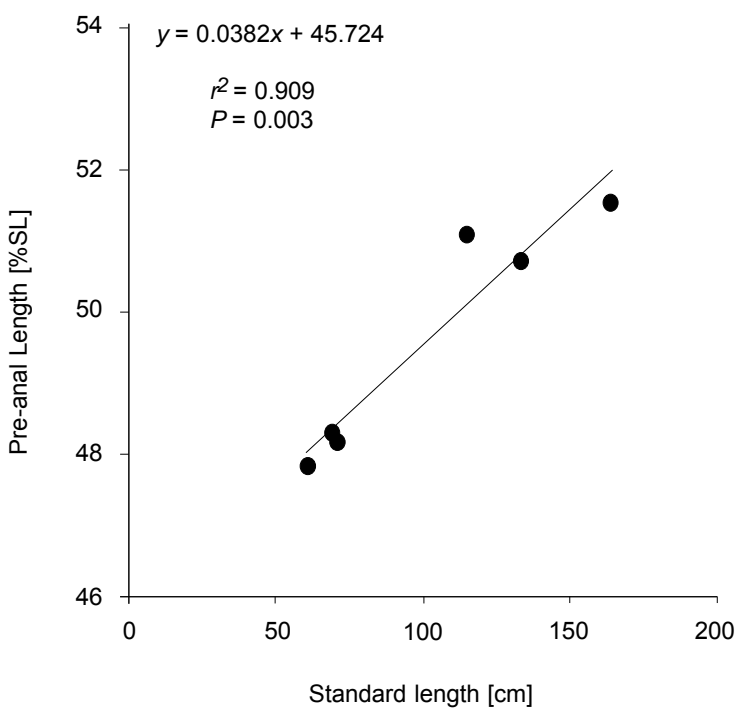

Fig. 3. Regression between pre-anal length (\%SL) and standard length (SL) of Evoxymetopon taeniatus; Data points used represent the presently reported study (Philippines) and central to south Japan (Sakiyama et al. 2011 and Hata et al. 2015) shape is not readily distinguishable from our specimens and from the figures of Nakamura and Parin (1993). All characteristics mentioned in the key below are based on Gill (1863), Nakamura and Parin (1993), Chakraborty et al. (2006), Sakiyama et al. (2011), Fricke et al. (2014), and the presently reported study. All illustrations in the guide are adapted from Nakamura and Parin (1993).

1a. From 78 to 88 dorsal fin elements, 1 st dorsal fin spine not elongate or no filament and shorter than the second, head profile with a steep sagittal crest slope (Fig. 4B), dorsal fin with a notch (Fig. 5B) $---------\rightarrow 2$

1b. More than 90 dorsal fin elements, 1st dorsal fin spine elongate or sword-shaped, head profile uniformly convex or with a gentle sagittal crest slope (Fig. 4A), dorsal fin without a notch (Fig. 5A) $\quad------\rightarrow 3$

2a. From 80 to 82 dorsal fin elements, membrane of the 1 st 9 dorsal fin elements blackish, dorsal fin notched at the 10th element, dorsal fin membrane after the notch transparent, anterior part of the head and snout not blackish, externally visible anal fin rays $15---------------\rightarrow E$. taeniatus

2b. Eighty three (83) dorsal fin elements, membrane of the 1st 5 dorsal fin elements blackish, dorsal fin notched at the 8th or 9th, dorsal fin membrane starting from 6th dorsal fin element transparent, anterior part of the head and snout margin blackish which continues along the anterior half of the dorsal fin base, externally visible anal fin rays $17----------\rightarrow$ E. moricheni

3a. Ninety (90) dorsal fin elements, 1st dorsal fin spine sword-shaped, externally visible anal fin rays $15-----------\rightarrow E$. macrophthalmus 
3b. From 92 to 93 dorsal fin elements, 1st dorsal fin spine elongate (Fig. 4A), externally visible anal fin rays $20------------------\longrightarrow E$. poeyi

Remarks. This is the first report of the occurrence of Evoxymetopon taeniatus in the Philippines and also the first to analyse meristic and morphometric trends of the species with relation to fish size. The two specimens identified were both caught off the coast (depth $>30$ meters) of Culasi, Antique in western Panay. Several attempts were made (until July 2016) to acquire additional samples from the same area as well as in the neighbouring municipalities, but none were successful. The species is benthopelagic and therefore not easy to catch. Perhaps the two specimens mixed together with the more commonly caught hairtail, Trichiurus lepturus, which were locally abundant at shallower depths in April and May.

One of the specimens $(133.1 \mathrm{~cm}$ SL) identified was in mature stage while the other had its gonads in the developing stage. These findings are the first reports of sizes of mature individuals of the species. Based on the stages of the specimens, we estimate that the length at first maturity is $114.5-133.1 \mathrm{~cm} \mathrm{SL}$. The larger identified specimen $(2.0 \mathrm{~kg})$ also weighed more than the maximum recorded weight of the species listed in FishBase $(1.7 \mathrm{~kg})$ (Froese and Pauly 2016), although the largest specimen ever reported $(163.8 \mathrm{~cm}$ SL) was caught in Japan (Sakiyama et al. 2011).

A detailed description of the species, as well as of other congeners is provided in Fricke et al. (2014). Their study, however, did not mention the number of dorsal fin spines with blackish membrane, nor the dorsal fin notch, which

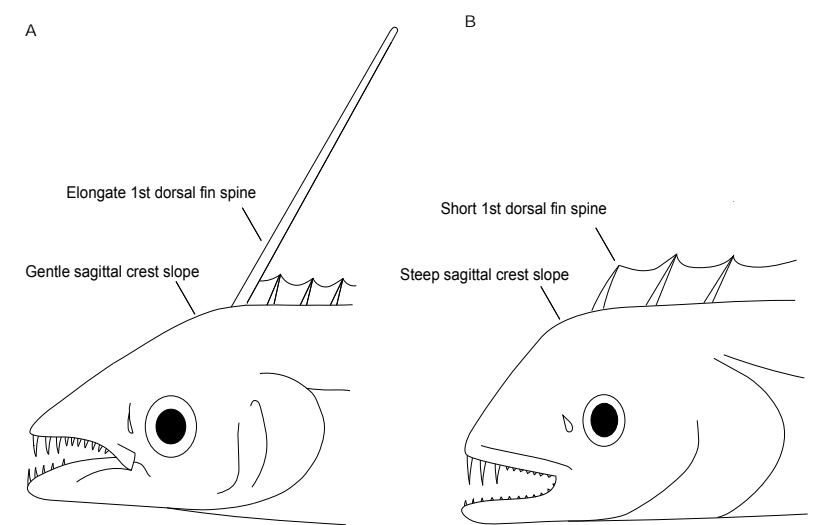

Fig. 4. Head profile of Evoxymetopon; with gentle sagittal crest, and elongate first dorsal fin spine (A) and with steep sagittal crest slope and short dorsal fin spine (B); Adapted from Nakamura and Parin (1993)

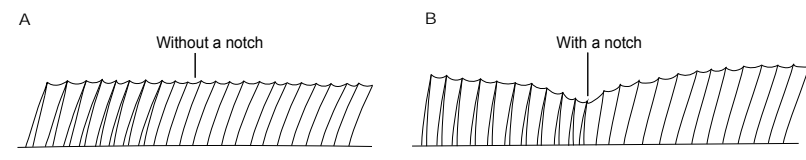

Fig. 5. Dorsal fin of Evoxymetopon without a notch (A) and with a notch (B); Adapted from Nakamura and Parin (1993) may be helpful in distinguishing one species from the other. Both specimens from the presently reported study show a blackish membrane covering the first nine dorsal fin spines (Fig. 2A-C) and a notch at the 10th dorsal fin spine (Fig. 2C). In E. moricheni, the blackish membrane is limited to the first five dorsal fin spines only, while the notch (inferred from the pictures of Fricke et al. 2014) is between the eighth or ninth dorsal fin spines. Note that the new taxon name in Fricke et al. (2014) is available from the first online version, pages 1-4, published on 14 March 2014.

The only significant trend in morphometrics was the increase in the pre-anal length in larger specimens, indicating that the anterior body grows more than the tail portion as individuals increase in size. This ontogenetic trend may be related to increased swimming abilities accompanying the shift from feeding on plankton and small fish as juveniles (Froese and Pauly 2016), to ambush fast swimming nekton such as anchovies, sardines, carangids, and squids (Chiou et al. 2006, Bittar et al. 2012) as adults. The relation between the size (SL) and the rest of the measurements were either too variable or covered differences that were too small to show significance. For example, the orbit diameter differed by only 1 percentage points of SL (3.1\% and $2.1 \%$, respectively) (Table 1) across the size range of the fish considered, but this small difference translates to a 30 percentage point relative change in the eye to body ratio, a feature that is important for visual feeders (Schmitz and Wainwright 2011). Trichiurids, however, are benthopelagic inhabitants of the continental shelf and slope (Nakamura and Parin 1993), where light penetration is limited. As predators, they rely heavily on other senses, such as chemo- and mechanoreception, rather than on vision (Mauchline and Gordon 1986). According to Bone and Moore (2008), trichiurids rely on the receptors in their lateral line in detecting preys via particle displacement.

This study reports the first record of the channel scabbardfish, Evoxymetopon taeniatus, in the Philippine waters, thus extending its known geographical distribution to the central Indo-Pacific. Meristic and morphometric trends with size and maturation stages were also analysed, which is the first for the species. Detailed descriptions and updated identification key for the four known Evoxymetopon species are also presented which will be helpful with their future identification.

\section{ACKNOWLEDGMENTS}

The authors would like to thank Dr. Hiroyuki Motomura of the Kagoshima University Museum and JSPS CCRENSEA Program for validating the identification and information of the species; researchers of the OceanBio Lab for assisting with the collection, identification, and photographic documentation; and the RARE, Inc. for funding the project.

\section{REFERENCES}

Anonymous 2016a. Marine and municipal fisheries: Volume of production by species, by region and by province. Country STAT Philippines. Philippine 
Statistics Authority. http://countrystat.psa.gov. $p h /$ cont $=10 \&$ pageid $=1 \& m a=D 10 P N V M P$ (Accessed in June 2016.)

Anonymous 2016b. [Occurrences: Evoxymetopon taeniatus.] Global Biodiversity Information Facility. http://www.gbif.org/occurrence/search?q= evoxymetopon + teaniatus\&taxon_key $=2389422$ (Accessed in June 2016.)

Anonymous 2016c. Species fact sheets; Trichiurus lepturus (Linnaeus, 1758). FAO, Fisheries and Aquaculture Department. http://www.fao.org/fishery/ species/2468/en (Accessed in June 2016.)

Bittar V.T., Awabdi D.R., Teles Tonini W.C., Vidal M.V.jr., Di Beneditto A.P.M. 2012. Feeding preference of adult females of ribbonfish Trichiurus lepturus through prey proximate-composition and caloric values. Neotropical Ichthyology 10 (1): 197203. DOI: $10.1590 / \mathrm{S} 1679-62252012000100019$

Bone Q., Moore R. 2008. Biology of Fishes. 3rd edn. Taylor and Francis Group, New York, NY, USA.

Carpenter K.E., Niem V.H (eds.) 2001. FAO species identification guide for fishery purposes. The living marine resources of the Western Central Pacific. Volume 6. Bony fishes part 4 (Labridae to Latimeriidae), estuarine crocodiles, sea turtles, sea snakes and marine mammals. Pp. 3709-3720. FAO, Rome.

Chakraborty A., Yoshino T., Iwatsuki Y. 2006. A new species of scabbard fish, Exovymetopon macrophthalmus (Scombroidei: Trichiuridae) from Okinawa, Japan. Ichthyological Research 53 (2): 137142. DOI. 10.1007/s10228-005-0319-X

Chiou W.-D., Chen C.-Y., Wang C.-M., Chen C.-T. 2006. Food and feeding habits of ribbonfish Trichiurus lepturus in coastal waters of south-western Taiwan. Fisheries Science 72 (2): 373-381. DOI: $10.1111 /$ j.1444-2906.2006.01159.x

Eschmeyer W.N., Fong J.D. 2016. Catalog of fishes: species by family/subfamily (version 29 September 2016). http://researcharchive.calacademy.org/research/ ichthyology/catalog/SpeciesByFamily.asp (Accessed in October 2016.)

Eschmeyer W.N., Fricke R., van der Laan R. (eds.) 2016. Catalog of fishes: genera, species (version 29 September 2016). http://researcharchive.calacademy. org/research/ichthyology/catalog/fishcatmain.asp (Accessed in October 2016.)

Fricke R., Golani D., Appelbaum-Golani B. 2014. Evoxymetopon moricheni, a new cutlassfish from the northern Red Sea (Teleostei: Trichiuridae).
Ichthyological Research $61 \quad$ (3): 293-297. DOI: $10.1007 / \mathrm{s} 10228-014-0394-y$

Froese R., Pauly D. (eds.) 2016. FishBase. [Version 06/2016] www.fishbase.org

Gill T. 1863. Synopsis of the family of lepturoids, and description of a remarkable new generic type. Proceedings of the Academy of Natural Sciences of Philadelphia 15: 224-229.

Hata H., Haraguchi Y., Motomura H. 2015. [Trichiurid fish Exovymetopon taeniatum obtained from Kagoshima Bay.] Nature of Kagoshima 41: 157-160. [In Japanese.]

Herre A.W.C.T. 1953. Checklist of Philippine fishes. US Government Printing Office, Washington, DC, USA.

Mauchline J., Gordon J.D.M. 1986. Foraging strategies of deep-sea fish. Marine Ecology_Progress Series 27: 227-238.

Nakamura I. 1985. FAO species catalogue. Vol. 5. Billfishes of the world. An annotated and illustrated catalogue of marlins, sailfishes, spearfishes and swordfishes known to date. FAO Fisheries Synopsis No. 125 .

Nakamura I., Parin N.V. 1993. FAO species catalogue. Vol. 15. Snake mackerels and cutlassfishes of the world (Families Gempylidae and Trichiuridae). An annotated and illustrated catalogue of the snake mackerels, snoeks, escolars, gemfishes, sackfishes, domine, oilfish, cutlassfishes, scabbardfishes, hairtails and frostfishes known to date. FAO Fisheries Synopsis No. 125.

Sakiyama T., Senou H., Onjuku A., Oshin S., Ito S. 2011. [First records of two species of the myliobatid rays, Aetobatus flagellum and Mobula diabolus from Sagami Bay with a certain record of a rare trichiurid fish, Evoxymetopon taeniatus.] Kanagawa Nature 32: 101-108. [In Japanese.]

Schmitz L., Wainwright P.C. 2011. Nocturnality constrains morphological and functional diversity in the eyes of reef fishes. BMC Evolutionary Biology 1 (1): 338-350. DOI: $10.1186 / 1471-2148-11-338$

Received: 3 October 2016 Accepted: 9 November 2016 Published electronically: 31 December 2016 